\title{
Establishing reference intervals for haematological and biochemical blood variables in Lika pramenka sheep
}

\author{
Ana Shek Vugrovečki ${ }^{1}$, Aleksandar Vojta ${ }^{2}$, and Miljenko Šimpraga ${ }^{1 *}$ \\ ${ }^{I}$ Department of Physiology and Radiobiology, Faculty of Veterinary Medicine, University of Zagreb, Zagreb, \\ Croatia \\ ${ }^{2}$ Division of Molecular Biology, Department of Biology, Faculty of Science, University of Zagreb, Zagreb, \\ Croatia
}

\begin{abstract}
$\overline{\text { SHEK VUGROVEČKI, A., A. VOJTA, M. ŠIMPRAGA: Establishing reference }}$ intervals of haematological and serum biochemical variables in Lika pramenka sheep. Vet. arhiv 87, 487-499, 2017.
\end{abstract}

\section{ABSTRACT}

Haematological and blood biochemical variables are key elements for routine assessment of animal health status, with implications in animal production and food safety. However, only reliable reference intervals of haematological and biochemical blood variables can provide the basis for accurate interpretation of the obtained blood results. Haematological and biochemical blood values critically dependent on living conditions, region, husbandry, rearing location, and diet. The aim of this study was to determine the reference intervals for selected important and informative haematological and blood biochemical variables for females of the Croatian indigenous sheep breed, Lika pramenka. We used several advanced statistical methods and assessed their applicability for determination of relevant reference intervals under conditions specific to indigenous sheep breeding. The results show that the reference intervals from the available literature are orientational but not adequate for the specific challenges encountered in raising indigenous breeds in their natural habitat. This was illustrated by the large number of clinically healthy animals with blood variable values falling outside the reference intervals given in the sources available previously.

Key words: indigenous breeds, reference interval, haematology, biochemical variables

\section{Introduction}

The reference intervals data for blood variables in many domestic animals have been known for many years (HOLMAN, 1946; KRAMER, 2000; KANEKO et al., 2008; PUGH and BAIRD, 2012). However, it should be noted that these reference intervals have been developed for universal use for sheep as a species, were collected over a long and unknown interval of time, and have not previously been verified for local use. When validating the

\footnotetext{
*Corresponding author:

Prof. Miljenko Šimpraga, Department of Physiology and Radiobiology, Faculty of Veterinary Medicine, University of Zagreb, Heinzelova 55, 10000, Zagreb, Croatia; Phone: +385 12390 170; +358 98312 053; E-mail: miljenko.simpraga@vef.hr
} 
reference interval, two main factors must be taken into account: 1) the proper selection of the method for determining the reference interval, and 2) the appropriate selection of the reference animal sample. Techniques for method assessment are relatively simple, if used in the same way as in the original study, but in veterinary medicine this is almost never the case. It is also important to use the same analytical systems to ensure quality and accuracy, which is also seldom possible primarily because of the speed with which the technologies and methods have developed in the past 50 years (CLSI, 2008).

Recently, many authors (ALONSO et al., 1997; ROUBIES et al., 2006) have indicated that haematological and biochemical blood values do not exhibit merely a small degree of breed specificity. They are also statistically significant dependent on living conditions, region, husbandry and rearing location, and especially diet (VOJTA et al., 2011; ŠIMPRAGA et al., 2013). This fact is particularly important in organic farming (VOJTA et al., 2011). Significant differences were also identified concerning sex, reproductive status (ROUBIES et al., 2006; BONEV et al., 2012) and the age of the animals (ROUBIES et al., 2006; PICCIONE et al., 2009).

In 2008, a document was published, guiding scientists and laboratories in determining reference intervals (CLSI, 2008). GEFFRÉ et al. (2009) published a review of this document and concluded that this guideline is applicable to veterinary medicine. . Both documents recommend testing all reference intervals, and their validation in each laboratory while using their own, conventional techniques for the variables and in a population as similar as possible to the one for which routine blood analysis is being done. They also give rigorous rules for the preanalytical, analytical and statistical methods for determining reference intervals. FRIEDRICHS et al. (2012) concluded that adoption of these guidelines by the entire veterinary community would provide easier communication and information dissemination. It is particularly important for herd health monitoring, as rearing and feeding conditions often cause variations in the concentrations of many serum/plasma metabolites, and their "exit" from the reference range in the published literature (BRAUN et al., 2010; KJELGAARD - HANSEN and LUNDORFF JENSEN, 2010).

So, the aim of this study was to determine reference intervals for selected haematological and blood biochemical variables for female, reproductive Lika pramenka sheep, by applying the classical and advanced statistical methods recommended by CLSI. The selected variables were chosen for their diagnostic value in routine use and their availability for common analysis.

\section{Materials and methods}

Animals. The study was carried out on a productive herd consisting of a Croatian pure bred indigenous sheep breed - Lika pramenka. 150 healthy ewes in anoestrus, aged 2-7 years were selected. The animals were clinically inspected by an authorized 


\section{A. Shek Vugrovečki et al.: Blood variables reference intervals in Lika pramenka sheep}

veterinarian. A detailed medical history was taken from the animals' keeper. All animals in the herd were registered with the Croatian Agricultural Agency. All procedures used in this research were in compliance with the European guidelines for the care and use of animals in research (Directive 2010/63/EC) and with approval from the Ethics Committee for Animal Experimentation, Faculty of Veterinary Medicine, University of Zagreb, Croatia (records no.: 640-01/12-17/84; file No. 251-61-01/139-12-2).

Husbandry and feeding. The selected sheep farm is situated in the Lika-Senj County, at Plitvice Lakes, in the village of Kompolje Koreničko ( $+44^{\circ} 44^{\prime} 58.14$ ", $+15^{\circ} 42^{\prime} 51.30^{\prime \prime}$ ), $582 \mathrm{~m}$ above sea level, Croatia. Given the climatic conditions in the region of Lika, the animals are kept in a semi-extensive system. The sheep graze on pasture when weather conditions permit it and eat hay at will (ad libitum) in the barn. Water is available ad libitum. Besides hay, the sheep are given cereals and ground corn in an amount of 0.5 to 1 $\mathrm{kg}$ per animal, particularly in winter time or when grazing is insufficient. They were also provided with "salt bricks" for licking. The animals were tested in mid-March at the time of sexual inactivity.

Blood sampling. Blood was collected once in the morning between 9 and 12 o'clock without prior fasting. The site of the venepuncture (v. jugularis) was trimmed and prepared for the procedure according to the good practice rules. For the collection the animals were held in a standing position between the assistant's legs while he lightly extended the sheep's head and neck. For haematological analysis blood was collected in $5 \mathrm{ml}$ vacuum glass vacutainer tubes with EDTA anticoagulant and SST II gel for biochemical analyses. After labelling, the samples were stored at $4{ }^{\circ} \mathrm{C}$ and transferred to the Laboratory of Physiology and Radiobiology, Faculty of Veterinary Medicine, University of Zagreb, for further processing. The blood for biochemical analysis in SST II gel tubes was left to clot for 30 minutes before centrifugation, which was performed on the farm. Further analysis was performed at the Department's laboratory within 12 hours.

Analysis. Before arriving at the Laboratory, the samples were stored in a cooler at 4 ${ }^{\circ} \mathrm{C}$. Upon arrival at the laboratory, and before analysis, the blood in the EDTA tubes was mixed in an automatic tube mixer until it warmed up to room temperature. Haematology analyses were undertaken on a total of 144 whole blood samples. After centrifugation at $1500 \mathrm{G}$ for 15 minutes, the samples of separated blood serum were divided into two Eppendorf tubes and stored in a freezer at $-20{ }^{\circ} \mathrm{C}$ for two weeks. Three serum samples were discarded due to haemolysis. After thawing at room temperature for 45 minutes, a total of 147 Lika pramenka sheep sera were analysed.

Blood samples analysis. Whole blood samples were analysed by a Beckman Coulter ACT Diff Hematology Blood Analyzer, using a veterinary program customized for sheep, Act Veterinary Applications Software, for the total number of leukocytes, the total number of red blood cells, platelet, haematocrit and haemoglobin count. Erythrocyte indexes 
were calculated by the built-in software. Quality control was performed according to the procedures recommended by the instrument manufacturer.

Blood serum analysis. The obtained blood serum samples were analysed for gammaglutamyl transferase (GGT), urea nitrogen (UREA), aspartate aminotransferase (AST), creatinine (CRE), total bilirubin (BIT), glucose (GLU), albumin (ALB), total protein (TP) and total cholesterol (CHO). The concentration of glucose, total cholesterol, total protein, albumin, creatinine, BIT, urea and GGT and AST activity was determined by spectrophotometry on an automatic analyser SABA 18 (AMS, Rome, Italy) using commercial kits (Diagnostics Ltd., Sisak, Croatia). Quality control was performed as recommended by the instrument manufacturer.

Statistical analysis. The reference limits of haematological and biochemical variables were determined by 1) the classical parametric method, 2) the parametric method after Box-Cox transformation, 3) the non-parametric method, and 4) by using robust statistics (HORN et al., 1999). Outliers were identified and rejected by using both Dixon and Tukey tests. The normality of distribution was tested by Lillefors' test, which is a modification of the Kolmogorov - Smirnov test (LILLIEFORS, 1967). For robust statistics, we used the method described in HORN et al. (1998). Confidence intervals for the robust method were estimated by bootstrap resampling.

Computer program. All calculations, bootstrap and values preparations were done using the "R language and environment for statistical analysis" (R Foundation for Statistical Computing, Vienna, Austria) and the packages: "boot", "Hmisc", "outliers", "forecast", "Norteste". The data were processed with the non-parametric method described by HARREL and DAVIS (1982) using the "Hmisc" package for the R environment.

\section{Results}

Summary results for the selected haematological and blood biochemical variables from 144 female, two to seven year old Lika pramenka sheep are presented in Table 1. After visual examination of blood samples, in six samples clots were determined and these samples were excluded from further analysis. After removal of outliers, more than 140 samples were used for reference interval determination. Four variables did not have a normal distribution and could not be normalized with the Box-Cox transformation. Depending on the normality of distribution and confidence interval (CI) for the reference interval $(\mathrm{RI})(<0.2)$ different methods were selected. Reference limits $\left(2.5^{\text {th }}\right.$ percentile and $95.7^{\text {th }}$ percentile) were calculated with a $90 \%$ confidence interval. Measurements of central tendencies are shown in Table 1. 
A. Shek Vugrovečki et al.: Blood variables reference intervals in Lika pramenka sheep

Table 1. Statistical results for selected haematological and biochemical blood variables in female, two to seven year old Lika pramenka sheep

\begin{tabular}{|c|c|c|c|c|c|c|}
\hline Variable & Unit & $\mathrm{N}$ & Distrib. & $\begin{array}{l}\text { mean/ } \\
\text { MED }\end{array}$ & $\begin{array}{l}\text { Lower limit } \\
(90 \% \mathrm{CI})\end{array}$ & $\begin{array}{c}\text { Upper limit } \\
(90 \% \mathrm{CI})\end{array}$ \\
\hline Leukocytes & $\left(10^{9} / \mathrm{L}\right)$ & 143 & log normal & 9.8 & $\begin{array}{c}5.6 \\
(5.2-5.95)\end{array}$ & $\begin{array}{c}17.0 \\
(15.9-18.1)\end{array}$ \\
\hline Erythrocytes & $\left(10^{12} / \mathrm{L}\right)$ & 143 & normal & 8.3 & $\begin{array}{c}6.6 \\
(6.4-6.8) \\
\end{array}$ & $\begin{array}{c}9.9 \\
(9.7-10.1) \\
\end{array}$ \\
\hline Haemoglobin & $(\mathrm{g} / \mathrm{L})$ & 144 & normal & 89.6 & $\begin{array}{c}74.5 \\
(72.7-76.4)\end{array}$ & $\begin{array}{c}104.7 \\
(102.9-106.5)\end{array}$ \\
\hline Haematocrit & $(\mathrm{L} / \mathrm{L})$ & 144 & non-normal & 0.27 & $\begin{array}{c}0.22 \\
(0.21-0.23)\end{array}$ & $\begin{array}{c}0.31 \\
(0.31-0.32)\end{array}$ \\
\hline $\mathrm{MCV}$ & (fL) & 144 & normal & 32.3 & $\begin{array}{c}28.8 \\
(28.4-29.2)\end{array}$ & $\begin{array}{c}35.8 \\
(35.4-36.2)\end{array}$ \\
\hline $\mathrm{MCH}$ & $(\mathrm{pg} / \mathrm{L})$ & 144 & normal & 10.9 & $\begin{array}{c}9.9 \\
(9.8-10.0)\end{array}$ & $\begin{array}{c}11.9 \\
(11.7-12.0)\end{array}$ \\
\hline $\mathrm{MCHC}$ & $(\mathrm{g} / \mathrm{L})$ & 144 & log normal & 336.7 & $\begin{array}{c}320 \\
(318-322)\end{array}$ & $\begin{array}{c}354 \\
(351-356)\end{array}$ \\
\hline Platelets & $\left(10^{9} / \mathrm{L}\right)$ & 143 & log normal & 380.6 & $\begin{array}{c}72.2 \\
(50-103.5)\end{array}$ & $\begin{array}{c}807.2 \\
(750.7-865.0)\end{array}$ \\
\hline GGT & $(\mathrm{U} / \mathrm{L})$ & 147 & non-normal & 38.0 & $\begin{array}{c}14.0 \\
(12.0-16.0)\end{array}$ & $\begin{array}{c}80.0 \\
(76.0-85.0)\end{array}$ \\
\hline UREA & $(\mathrm{mmol} / \mathrm{L})$ & 147 & normal & 8.62 & $\begin{array}{c}6.66 \\
(6.51-6.88)\end{array}$ & $\begin{array}{c}10.92 \\
(10.66-11.13)\end{array}$ \\
\hline AST & $(\mathrm{U} / \mathrm{L})$ & 145 & log normal & 151.8 & $\begin{array}{c}110.7 \\
(107.2-114.4)\end{array}$ & $\begin{array}{c}241.5 \\
(225.6-259.8)\end{array}$ \\
\hline CRE & $(\mu \mathrm{mol} / \mathrm{L})$ & 145 & log normal & 86.6 & $\begin{array}{c}74.5 \\
(73.3-75.8)\end{array}$ & $\begin{array}{c}103.2 \\
(100.9-105.7)\end{array}$ \\
\hline BIT & $(\mu \mathrm{mol} / \mathrm{L})$ & 141 & log normal & 7.9 & $\begin{array}{c}5.0 \\
(4.7-5.4)\end{array}$ & $\begin{array}{c}11.0 \\
(10.6-11.4)\end{array}$ \\
\hline GLU & $(\mathrm{mmol} / \mathrm{L})$ & 147 & log normal & 2.575 & $\begin{array}{c}1.58 \\
(1.46-1.70) \\
\end{array}$ & $\begin{array}{c}3.72 \\
(3.62-3.87) \\
\end{array}$ \\
\hline ALB & $(\mathrm{g} / \mathrm{L})$ & 145 & non-normal & 42.0 & $\begin{array}{c}34.0 \\
(31.0-36.0)\end{array}$ & $\begin{array}{c}48.0 \\
(47.0-49.0)\end{array}$ \\
\hline $\mathrm{TP}$ & $(\mathrm{g} / \mathrm{L})$ & 146 & normal & 78.55 & $\begin{array}{c}67.0 \\
(64.0-68.0) \\
\end{array}$ & $\begin{array}{c}91.0 \\
(89.0-96.0) \\
\end{array}$ \\
\hline $\mathrm{CHO}$ & $(\mathrm{mmol} / \mathrm{L})$ & 147 & non-normal & 1.56 & $\begin{array}{c}0.74 \\
(0.70-0.81)\end{array}$ & $\begin{array}{c}2.47 \\
(2.35-2.60)\end{array}$ \\
\hline
\end{tabular}

$\mathrm{N}$ - number of animals in the sample; Distrib. - distribution; mean/MED - mean or median (depending on statistical method); Lower limit - the 2.5 th percentile $\mathrm{CI}_{90}-90 \%$ confidence interval for the $2.5 \%$ percentile; Upper limit - 97.5 percentile; $97.5 \% \mathrm{CI}_{90}{ }^{-}$confidence interval for the $97.5 \%$ percentile; method - chosen statistical method for reference interval determination; MCV - mean corpuscular volume; $\mathrm{MCH}$ - Mean corpuscular haemoglobin; MCHC- Mean corpuscular haemoglobin concentration; GGT - gamma - glutamyl transferase; UREA - blood urea nitrogen; AST - aspartate aminotransferase; CREA - creatinine; BIT - total bilirubin; GLU - glucose; ALB - albumin; TP - total protein; CHO - cholesterol 
Comparing reference intervals from this research with those for sheep in KRAMER (2000), the reference intervals calculated in this research are wider and shifted more to the right (towards higher values) for the total number of leukocytes, while the total numbers of red blood cells and all the erythrocyte constants have lower reference limits values. Comparing calculated reference intervals for sheep blood biochemical variables with those in KANEKO et al. (2008), the reference intervals for GGT, CRE, GLU and CHO have shifted to the left (towards lower values), for UREA, BIT, ALB and TP they have shifted to the right (toward higher values), and the reference interval for AST became narrower.

\section{Discussion}

In this study, we determined the reference intervals of key haematological and biochemical variables in the blood of 150 Croatian female indigenous sheep of the Lika pramenka breed, during the dry period and anoestrus. The results are shown in Table 1. Reference intervals were determined as recommended by the CLSI (2008) document.

Selection of females as the reference population places a limit on the use of the obtained reference intervals. Care should be taken when extrapolating the results to males, as they were not included in the reference population. Along the same lines, seasonal changes might affect the analyte values (KRAJNICAKOVA et al., 1997; TIBBO et al., 2004), which means that the estimated reference intervals are most reliable for the season when the reference population was sampled (in March).

Other authors suggest that haematological variables in sheep may be affected by various internal and external factors such as age (ALONSO et al., 1997; EGBE-NWIYI et al., 2000; TIBBO et al., 2004; JENKO, 2009; ADDASS, 2011), gender (EGBE-NWIYI et al., 2000; TIBBO et al., 2004; ADDASS, 2011), season (KRAJNICAKOVA et al., 1997; TIBBO et al., 2004), shearing (CARCANGIU et al., 2008), breed (TIBBO et al., 2004; BINEV et al., 2007; RADIN et al., 2008; DIAS et al., 2010; ADDASS, 2011; VOJTA et al., 2011), lactation (BOUDEBZA et al., 2014) and nutrition (ANTUNOVIĆ et al., 2001; DIAS et al., 2010), and breeding model (VOJTA et al., 2011). Despite the many influences on the values of haematological variables in the blood of sheep, in most cases the values are within relatively narrow limits which usually correspond to the wide reference ranges published in the relevant textbooks (FELDMAN et al., 2000; KANEKO et al., 2008; PUGH and BAIRD, 2012). The results of this research are in agreement with our findings if we compare only the mean value obtained by descriptive statistics. However, considering that they were in their research they engaged in the study of various effects on haematological variables in the blood of sheep, rather than establishing reference intervals, the results cannot be directly compared with the reference intervals obtained in our study. A direct comparison would require a detailed insight into the original data, and additional information about the pre-analytical and analytical factors, and harmonizing statistical calculation methods. 


\section{A. Shek Vugrovečki et al.: Blood variables reference intervals in Lika pramenka sheep}

The haematological reference intervals of Lika Pramenka ewes can be compared with those reported by ŠIMPRAGA et al. (2013), who determined the reference blood intervals for Dalmatian pramenka - another Croatian indigenous sheep breed .For comparison, the reference intervals are shown in Table 2. They can also be compared with the results of LEPHERD et al. (2009) who published reference blood intervals for female merino lambs bred in Australia, using new, more rigorous (sample selection, sample collection techniques, statistical method selection) rules and methods for reference interval determination. More differences can be seen if our data is compared with the reference intervals from relevant textbooks (KANEKO et al. 2008; PUGH and BAIRD, 2012).

Table 2. Reference intervals of selected haematological and biochemical blood variables in Lika pramenka female sheep and those from relevant literature

\begin{tabular}{|l|c|c|c|c|c|}
\hline \multicolumn{1}{|c|}{ Variable } & Unit & Lika pramenka & Textbooks & $\begin{array}{c}\text { Lepherd et al., } \\
(2009)\end{array}$ & $\begin{array}{c}\text { Šimpraga et al., } \\
(2013)\end{array}$ \\
\hline Leukocytes & $\left(10^{9} / \mathrm{L}\right)$ & $5.6-17.0$ & $4.0-8.0$ & $5.1-15.9$ & $3.02-15.64$ \\
\hline Erythrocytes & $\left(10^{12} / \mathrm{L}\right)$ & $6.62-9.92$ & $9.0-15.0$ & $9.2-13.0$ & $7.81-12.77$ \\
\hline Haemoglobin & $(\mathrm{g} / \mathrm{L})$ & $74.55-104.7$ & $90-150$ & $105-137$ & $78.1-134.7$ \\
\hline Haematocrit & $(\mathrm{L} / \mathrm{L})$ & $0.22-0.31$ & $0.27-0.45$ & $0.28-0.39$ & $0.24-0.41$ \\
\hline MCV & $(\mathrm{fL})$ & $28.8-35.8$ & $28-40$ & $28.0-35.0$ & $28.6-34.8$ \\
\hline MCH & $(\mathrm{pg} / \mathrm{L})$ & $9.9-11.9$ & $8.0-12.0$ & $10.0-13.0$ & $9.54-11.0$ \\
\hline MCHC & $(\mathrm{g} / \mathrm{L})$ & $320-353$ & $310-340$ & $332-392$ & $284-362$ \\
\hline Platelets & $\left(10^{9} / \mathrm{L}\right)$ & $75-807$ & $800-1100$ & $426-1142$ & $0-731$ \\
\hline GGT & $(\mathrm{U} / \mathrm{L})$ & $14.3-80$ & $20-52$ & $56-110$ & $31.7-71.7$ \\
\hline UREA & $(\mathrm{mmol} / \mathrm{L})$ & $6.7-10.9$ & $2.86-7.14$ & $5.0-9.1$ & $3.5-7.8$ \\
\hline AST & $(\mathrm{U} / \mathrm{L})$ & $110.7-241.5$ & $60-280$ & $83.0-140$ & $66.2-129.3$ \\
\hline CRE & $(\mu \mathrm{mol} / \mathrm{L})$ & $74.5-103.2$ & $106-168$ & $35.0-64.0$ & $98-144$ \\
\hline BIT & $(\mu \mathrm{mol} / \mathrm{L})$ & $5.0-11.0$ & $1.71-8.55$ & $0.0-3.0$ & $/$ \\
\hline GLU & $(\mathrm{mmol} / \mathrm{L})$ & $1.4-3.7$ & $2.78-4.44$ & $2.7-4.8$ & $2.9-4.3$ \\
\hline ALB & $(\mathrm{g} / \mathrm{L})$ & $35.4-47.5$ & $24-30$ & $30.0-37.0$ & $28.5-44.7$ \\
\hline TP & $(\mathrm{g} / \mathrm{L})$ & $66.7-91.0$ & $60-79$ & $51.0-64.0$ & $66.8-87.4$ \\
\hline CHO & $(\mathrm{mmol} / \mathrm{L})$ & $0.74-2.47$ & $1.35-1.97$ & & $/$ \\
\hline
\end{tabular}

Textbooks - KRAMER (2000) and KANEKO et al. (2008); MCV - mean corpuscular volume; MCH - Mean corpuscular haemoglobin; MCHC - Mean corpuscular haemoglobin concentration; GGT- gamma - glutamyl transferase; UREA - blood urea nitrogen; AST - aspartate aminotransferase; CREA - creatinine; BIT - total bilirubin; GLU - glucose; ALB - albumin; TP - total protein; CHO - cholesterol

Like haematological variables, biochemical blood variables are also influenced by external factors, but the impact is often stronger and more readily detectable (ŠIMPRAGA et al., 2013). That difference is smaller if we compare Croatian indigenous sheep breeds with each other (ANTUNOVIĆ et al., 2004), but greater if we compare them with sheep 
A. Shek Vugrovečki et al.: Blood variables reference intervals in Lika pramenka sheep

from other countries (CARCANGIU et al., 2008; BONEV et al., 2012; SOWKAT et al., 2014). This is likely because the biochemical markers in the blood of sheep can be much more strongly affected by various local factors, such as husbandry and climate (ŠIMPRAGA et al., 2013). Also, biochemical blood variables are influenced by the age of the animal (ROUBIES et al., 2006; ADDASS, 2011), pregnancy and lactation (CARCANGIU et al., 2007), the number of lambings (ROUBIES et al., 2006; BOUDEBZA et al. 2014), as well as the botanical composition of the pasture, and water availability (ANTUNOVIĆ et al., 2010; ANTUNOVIĆ et al., 2011).

Table 3. The percentage of healthy Lika pramenka sheep from the sample whose selected haematological and biochemical blood variables are outside the reference intervals given in selected literature

\begin{tabular}{|c|c|c|c|c|c|}
\hline Variable & unit & $\begin{array}{l}\text { Total No. of } \\
\text { animals in the } \\
\text { sample (after } \\
\text { removal of } \\
\text { extreme values) }\end{array}$ & $\begin{array}{l}\text { \% of the } \\
\text { samples outside } \\
\text { ref. inter. from } \\
\text { Šimpraga et al. } \\
\text { (2013) }\end{array}$ & $\begin{array}{c}\text { \% of samples } \\
\text { outside ref. } \\
\text { inter. from } \\
\text { relevant } \\
\text { textbooks }\end{array}$ & $\begin{array}{l}\% \text { of the } \\
\text { samples outside } \\
\text { ref. inter. from } \\
\text { Lepherd et al. } \\
\text { (2009) }\end{array}$ \\
\hline Leukocytes & $\left(10^{9} / \mathrm{L}\right)$ & 143 & 4 & 76 & 6 \\
\hline Erythrocytes & $\left(10^{12} / \mathrm{L}\right)$ & 143 & 31 & 80 & 85 \\
\hline Haemoglobin & $(\mathrm{g} / \mathrm{L})$ & 144 & 6 & 97 & 97 \\
\hline Haematocrit & $(\mathrm{L} / \mathrm{L})$ & 144 & 14 & 70 & 65 \\
\hline $\mathrm{MCV}$ & (fL) & 144 & 12 & 8 & 8 \\
\hline $\mathrm{MCH}$ & $(\mathrm{pg} / \mathrm{L})$ & 144 & 40 & 1 & 3 \\
\hline $\mathrm{MCHC}$ & $(\mathrm{g} / \mathrm{L})$ & 144 & 1 & 34 & 28 \\
\hline Platelets & $\left(10^{9} / \mathrm{L}\right)$ & 143 & 85 & 97 & 54 \\
\hline GGT & $(\mathrm{U} / \mathrm{L})$ & 147 & 46 & 42 & 42 \\
\hline UREA & $(\mathrm{mmol} / \mathrm{L})$ & 148 & 78 & 91.2 & 35 \\
\hline AST & $(\mathrm{U} / \mathrm{L})$ & 145 & 80 & 7 & 66 \\
\hline CRE & $(\mu \mathrm{mol} / \mathrm{L})$ & 145 & 94 & 98.6 & 100 \\
\hline BIT & $(\mu \mathrm{mol} / \mathrm{L})$ & 141 & 1 & 25 & 100 \\
\hline GLU & $(\mathrm{mmol} / \mathrm{L})$ & 147 & 67 & 64 & 57 \\
\hline ALB & $(\mathrm{g} / \mathrm{L})$ & 145 & 19 & 100 & 33 \\
\hline TP & $(\mathrm{g} / \mathrm{L})$ & 146 & 8 & 47.2 & 100 \\
\hline $\mathrm{CHO}$ & $(\mathrm{mmol} / \mathrm{L})$ & 148 & 1 & 58.1 & 1 \\
\hline
\end{tabular}

relevant textbooks - KRAMER (2000) and KANEKO et al. (2008); MCV - mean corpuscular volume; MCH - Mean corpuscular haemoglobin; MCHC - Mean corpuscular haemoglobin concentration; GGT- gamma glutamyl transferase; UREA - blood urea nitrogen; AST - aspartate aminotransferase; CREA - creatinine; BIT - total bilirubin; GLU - glucose; ALB - albumin; TP - total protein; CHO - cholesterol

With the results obtained in this study and the reference intervals shown in Tables 1 and 2 , it has been demonstrated that the reference ranges of haematological and biochemical 


\section{A. Shek Vugrovečki et al.: Blood variables reference intervals in Lika pramenka sheep}

blood factors of Lika pramenka ewes are indeed different from those observable in relevant textbook literature, as shown in Table 3. Comparing the blood values of sampled animals with thee reference intervals from relevant textbooks such as KRAMER (2000) for haematology and KANEKO et al. (2008) for blood biochemistry, as Table 3, it can be seen that although they were collected from healthy animals, a large percentage of blood values are outside the book's reference intervals. Reference values should encompass $95 \%$ of a healthy population (CLSI, 2008) so around $5 \%$ of healthy animals could be outside the reference intervals. It is also evident that this percentage is smaller when data is compared to reference intervals presented in the studies made with new, stricter criteria for setting the reference interval, such as in LEPHERD et al. (2009), or similar reference populations as in VOJTA et al. (2011) and ŠIMPRAGA et al. (2013). Although smaller, the percentage of sample animals with values above or below the given reference limits is still more than 5\% (Table 3).

\section{Conclusions}

We confirm the necessity for determining specific haematological and blood biochemical variables reference intervals for herds raised under different conditions, especially for indigenous species. We found that for a sample size of 150 individuals there is no universally applicable statistical method for reference value determination for all blood variables. Due to the low sensitivity to extreme values, the possibility of calculating satisfactory results from smaller samples and the fact that it does not assume normality of distribution, we recommend the robust method for determination of reference intervals for biological samples. Nevertheless, we recommend the application of at least one more statistical method for determination of reference intervals (parametric transformed parametric or nonparametric method) to verify the quality of the reference population. Reference intervals from the relevant and available literature are more for orientation than useful, taking into account the large number of clinically healthy animals whose blood variable values fell outside the given reference intervals.

The reference intervals obtained in this study are the basis for further research into indigenous sheep breeds, but also serve to demonstrate the need for determination of reference blood intervals in all other indigenous breeds of sheep, and other animals.

\section{Acknowledgements}

The study was performed on samples collected during the research project "Standardization of some health indicators of Croatian indigenous sheep breeds", by research leader Prof. Miljenko Šimpraga, Ph.D., DVM, and funded by the Ministry of Science, Education and Sports of the Republic Croatia (053-1780469-2110). 
A. Shek Vugrovečki et al.: Blood variables reference intervals in Lika pramenka sheep

\section{Conflict of interest statement}

None of the authors has any financial or personal relationships that could inappropriately influence or bias the content of the paper.

\section{References}

ADDASS, P. (2011): Genotype and seasonal variation in testes and paired epididymal sperm production among indigenous bull cattle in Mubi Adamawa State, Nigeria. Agr. Biol. J. N. Am., 2, 19-22.

ALONSO, A. J., D. E. TERESA, R., GARCÍA, M. GONZÁLEZ, J. R., M. VALLEJO (1997): The Effects of age and reproductive status on serum and blood parameters in merino breed sheep. J. Vet. Med. A., 44, 223-231.

ANTUNOVIĆ, Z., I. MARIĆ, Z. STEINER, M. VEGARA, J. NOVOSELEC (2011): Blood Metabolic Profile of the Dubrovnik Sheep - Croatian Endangered Breed, Maced. J. Anim. Sci. $1,35-38$.

ANTUNOVIĆ, Z., J. NOVOSELEC, M. ŠPERANDA, M. ĐIDARA (2010): Utjecaj stadija laktacije na koncentracije biokemijskih pokazatelja u krvi ovaca, Zbornik radova 45. hrvatskog i 5. međunarodnog simpozija agronoma, Marić, S. i Lončarić, Z. (ur.). Osijek: Poljoprivredni fakultet Sveučilišta Josipa Jurja Strossmayera u Osijeku, pp. 1009-1013.

ANTUNOVIĆ, Z., M. ŠPERANDA, Z. STEINER (2004): The influence of age and the reproductive status of the blood indicators of the ewes. Arch. Tierzucht 47, 265-273.

ANTUNOVIĆ, Z., G. BUKVIĆ, Z. STEINER, M. ANTUNOVIĆ, D. RASTIJA (2001): Dynamic of rotation pastures quality and influence on some biochemical indicators in sheep blood. Krmiva 43, 301-308.

BINEV, R., A. RUSSENOV, P. SLAVOVA, S. LALOVA (2007): Studies on some paraclinical indices in lambs of various breeds. Trakia J. Sci. 5, 79-83.

BONEV, G., R. SLAVOV, S. GEORGIEVA, P. BADAROVA, S. OMAR (2012): The effects of productive status and age on some blood serum parameters before oestrous synchronisation in Awassi and Awassi crosses sheep breed. J. Agr. Sci. Tech. 4, 117-119.

BRAUN, J. P., C. TRUMEL, P. BÉZILLE (2010): Clinical biochemistry in sheep: A selected review. Small Ruminant Res. 92, 10-18.

BOudeBZA, A., A. BENSEGUENI, M. C. ABDELDJELIL, C. BELATRECHE (2014): Some blood biochemical parameter changes in Ouled Djellal ewes during lactation and dry period. Ann. Bio. Res. 5, 42-45.

CARCANGiU, V., G. M. VACCA, A. PARMEGGiAni, M. C. MURA, M. PAZZOLA, M. L DETTORI, P. P. BINI (2008): The effect of shearing procedures on blood levels of growth hormones, Cortisol and Other Stress Haematolochemical Parameters In Sarda Sheep. Animal 2, 606-612.

CARCANGIU, V., G. M. VACCA, M. C. MURA, M. L. DETTORI, M. PAZZOLA, M. FIORI, P. P. BINI (2007): Blood parameters during lactation and dry period in Sarda sheep breed. 
A. Shek Vugrovečki et al.: Blood variables reference intervals in Lika pramenka sheep

Proceedings XV International Congres of Mediterranean Federation for Health and Production of Ruminants, 15-19 May, Kusadasi, Turkey, pp. 115-120.

CLINICALAND LABORATORY STANDARDS INSTITUTE (2008): Defining, Establishing, and Verifying Reference Response in the Clinical Laboratory; Approved Guideline. $3^{\text {rd }}$ ed. CLSI document C28-A3c, Wayne, P. A., Clinical and Laboratory Standards Institute, 28, pp. 3.

DIAS, I. R, A. VIEGASC, A. M. SILVA, H. F. PEREIRA., C. P. SOUSA, P. P. CARVALHO, A. S. CABRITA, P. J. FONTES, S. R., SILVA, J. M. T. AZEVEDO (2010): Haematological and biochemical parameters in Churra-da-TerraQuente ewes from the northeast of Portugal. Arq. Bras. Med. Vet. Zootec. 62, 265-272.

EGBE-NWIYI, T. N., S. C. NWAOSU, H. A. SALAMI (2000): Haematological values of apparently healthy sheep and goats as influenced by age and sex in the arid zone of Nigeria. Afr. J. Biomed. Res. 3, 109-115.

FELDMAN, B. V., J. G. ZINKL, N. C. JAIN, O. W. SCHALM (2000): Schalm's Veterinary Hematology, Lippincott Williams \& Wilkins, Philadelphia, pp. 1076.

FRIEDRICHS, K. R., K. E. HARR, K. P. FREEMAN, B. SZLADOVITS , R. M. WALTON , K. F. BARNHART, J. BLANCO-CHAVEZ (2012): ASVCP reference interval guidelines: determination of de novo reference intervals in veterinary species and other related topics. Vet. Clin. Pathol. 41, 441-453.

GEFFRÉ, A., K. FRIEDRICHS, K. HARR, D. CONCORDET, J. P. TRUMEL, C. BRAUN (2009): Reference values: a review. Vet. Clin. Pathol. 38, 288-298.

HARREL, F. E., C. E. DAVIS (1982): A new distribution free quantile estimator. Biometrika 69, 635-670.

HOLMAN, H. H. (1946): Studies on the haematology of the horse, ox, and sheep. Proceedings of the Royal Society of Medicine 40, 7-9.

HORN, P. S., A. J. PESCE, B. E. COPELAND (1998): A robust approach to reference interval estimation and evaluation. Clin. Chem. 44, 622-631.

HORN, P. S., A. J. PESCE, B. E. COPELAND (1999): Reference Interval Computation Using Robust vs. Parametric and Nonparametric Analyses. Clin. Chem. 45, 2284-2285.

JENKO, Z. (2009): Some reproductive, physiological and biochemical variables in bovec sheep, in jezersko-solchava sheep and istrian sheep. PhD Thesis, Univerza v Ljubljani, Ljubljana, Slovenija.

KANEKO, J. J., J. W. HARVEY, M. L. BRUSS (Eds.) (2008): Clinical Biochemistry of Domestic Animals. $6^{\text {th }}$ ed., Academic Press, Inc., San Diego, London, Boston, New York, Sydney, Tokyo, Toronto, pp. 882-888.

KJELGAARD-HANSEN M., A. LUNDORFF JENSEN (2010): Reference Intervals In: Schalm's Veterinary Hematology. $6^{\text {th }}$ ed. (Weis D. J., J. K. Wardrop, Eds.). Philadelphia, Blackwell Publishing Ltd., 1034-1038.

KRAJNICAKOVA, M., E. BEKEOVA, J. KACMARIK, I. VALOCKY, V. HENDRICHOVSKY, I. MARACEK (1997): Comparison of selected hematological parameters in September-and February-lambing of Slovak Merino sheep. Small Ruminant Res. 26, 131-135. 
A. Shek Vugrovečki et al.: Blood variables reference intervals in Lika pramenka sheep

KRAMER, J. W. (2000): Normal hematology of cattle, Sheep, and Goats In: Schalm's Veterinary Hematology (Kramer, B. F., J. G, Zinkl, N. C. Jain, Eds.), $5^{\text {th }}$ ed., Baltimore, Lippincot Williams \& Wilkins, pp. 1057-1084.

LEPHERD, M. L., P. J. CANFIELD, G. B. HUNT, K. L. BOSWARD (2009): Haematological, biochemical and selected acute phase protein reference intervals for weaned female Merino lambs. Aust. Vet. J. 87, 5-11.

LILLIEFORS, H. W. (1967): On the Kolmogorov-Smirnov test for normality with mean and variance unknown. J. Am. Statist. Assoc. 62, 399-402.

PICCIONE, G., G. CAOLA, C. GIANNETTO, F. GRASSO, S. CALANNI RUNZO, A. ZUMBO, P. PENNISI (2009): Selected biochemical serum parameters in ewes during pregnancy, postparturition, lactation and dry period. Anim. Sci. Pap. Rep. 27, 321-330.

PUGH, D. G., A. N. BAIRD (2012): Sheep and Goat Medicine, $2^{\text {nd }}$ ed., Saunders. Philadelphia, pp. 597.

RADIN, L., M. ŠIMPRAGA, A. VOJTA, A. MARINCULIĆ (2008): Indigenous sheep in organic livestock production in karst areas of Croatia. $16^{\text {th }}$ IFOAM Organic World Congress, June 1620, Modena, Italy, Archived at http://orgprints.org/11569

ROUBIES, N., N. PANOUSIS, A. FYTIANOU, P. D. KATSOULOS, N. GIADINIS, H. KARATZIAS (2006): Effects of age and reproductive stage on certain serum biochemical parameters of chios sheep under Greek rearing conditions. J. Vet. Med. A Physiol. Pathol. Clin. Med. 53, 277-281.

SOWKAT, B. A., M. R. MANZOOR, A. R. AHMAD, B. A. SHEIKH, H. ISHRAQ, S. BASHIR, H. M. KHAN (2014): Impact of age and gender on some blood biochemical parameters of apparently healthy small ruminants of sheep and goats in Kashmir valley India, Int. J. Agric. Sc. \& Vet. Med. 2, 22-27.

ŠIMPRAGA, M., T. ŠMUC, K. MATANOVIĆ, L. RADIN, A. SHEK-VUGROVEČKI, I. LJUBIČIĆ, A. VOJTA (2013): Reference intervals for organically raised sheep: Effects of breed, location and season on hematological and biochemical parameters. Small Ruminant Res. 112, 1-6.

TIBBO, M., Y. JIBRIL., M. WOLDEMESKEL, F. DAWO, K., ARAGAW, J. E. O. REGE (2004.): Factors affecting hematological profiles in three ethiopian indigenous goat breeds, Intern. J. Appl. Res. Vet. Med. 2, 297-309.

VOJTA, A., A. SHEK-VUGROVEČKI, L. RADIN, M. EFENDIĆ, J. PEJAKOVIĆ, M. ŠIMPRAGA (2011): Hematological and biochemical reference intervals in Dalmatian pramenka sheep estimated from reduced sample size by bootstrap resampling. Vet. arhiv 81, 25-33.

Received: 14 March 2016

Accepted: 29 June 2016 
A. Shek Vugrovečki et al.: Blood variables reference intervals in Lika pramenka sheep

\section{SHEK VUGROVEČKI, A., A. VOJTA, M. ŠIMPRAGA: Određivanje referentnih intervala hematoloških i biokemijskih pokazatelja u krvi ovaca pasmine lička pramenka. Vet. arhiv 87, 487-499, 2017. \\ SAŽETAK}

Hematološki i biokemijski krvni pokazatelji ključan su element pri rutinskom procjenjivanju zdravstvenog statusa životinja, produktivnosti životinja te sigurnosti hrane. Međutim, samo pouzdani referentni intervali hematoloških i biokemijskih pokazatelja u krvi mogu pružiti osnovu za precizno tumačenje dobivenih rezultata. Hematološke i biokemijske vrijednosti u krvi uvelike ovise o uvjetima držanja, regiji u kojoj se životinje drže, načinu uzgoja, mjestu uzgoja te hranidbi životinja. Cilj ovog istraživanja bio je utvrditi pouzdane referentne intervale za odabrane važne i informativne hematološke i biokemijske pokazatelje u krvi ženskih životinja hrvatske izvorne pasmine ličke pramenke. U istraživanju su korištene napredne statističke metode te je procijenjena njihova primjenjivost za određivanje relevantnih referentnih intervala u specifičnim uvjetima ovčarstva izvornim pasminama. Rezultati pokazuju da su referentni intervali iz dostupne literature orijentacijski, ali ne i dovoljni pri specifičnim izazovima u uzgoju izvornih pasmina u njihovom prirodnom staništu. To je ilustrirano velikim brojem klinički zdravih životinja čije se vrijednosti krvnih pokazatelja nalaze izvan referentnih intervala danim u prijašnjim istraživanjima.

Ključne riječi: izvorna pasmina, referentni intervali, hematološki pokazatelji, biokemijski pokazatelji 
